\title{
TREATMENT OF PARALYSIS OF THE FLEXORS OF THE ELBOW
}

\author{
Anne Segal, Paris, France, H. J. Seddon and D. M. Brooks, London, England \\ From the Institute of Orthopaedics, Royal National Orthopaedic Hospital, London and Stanmore
}

This paper presents the results of operations designed to restore active flexion of the elbow. The types of operation considered are: 1) transplantation of pectoralis major into biceps (Clark's (1946) operation and the Brooks-Seddon operation (1959)); 2) transplantation of triceps into biceps; and 3) proximal transplantation of the common flexor and extensor origins-Steindler's operation.

\section{THE CASES}

We have studied forty-one patients who had lost active elbow flexion, either from a traction lesion of the brachial plexus or after an attack of poliomyelitis. The average period of post-operative observation was four years and eight months, the shortest period being ten months, the longest eleven years.

\section{METHOD OF ANALYSIS}

It proved necessary to assess the subjective as well as the objective results of these operations. It is probably fair to group cases of brachial plexus injury and poliomyelitis together for objective assessment, whereas it can be misleading to do so when gauging subjective results. A slight gain in movement can be most valuable to the patient with poliomyelitis; by contrast the impairment of sensibility which often follows lesions of the brachial plexus may seriously limit the usefulness of the limb despite a significant motor improvement. In every case a full examination of the arm was carried out. Records were made showing the ranges of passive and active movement, the power of individual muscle groups, and simultaneous movements of shoulder, wrist and fingers on flexion of the elbow. In the cases of brachial plexus injury the residual sensory disturbance was noted. The objective results were graded as follows:

Excellent-Powerful contraction throughout the full range of movement.

Good-Contraction adequate to produce at least movement against gravity through a useful range.

Fair-The same power of contraction through a more restricted range.

Failure-Inability to contract against gravity, or ability to produce only a useless range of movement.

Full extension is designated as 0 degrees. A useful range of movement is considered to be an arc of not less than 60 degrees which must include a position of flexion of not less than 120 degrees. A useless range of flexion is of less than 60 degrees from the fully extended position.

Each patient was asked to give his view on the result of the operation. Was it a success? Had it improved the function of the limb as a whole? What work could he do? Had the appearance of the limb improved? The subjective results were graded as follows:

Excellent-." The operation has been a great success."

Good-" "It has been successful up to a point."

Poor-" There has been no real change."

Failure-" "It has been a disappointment."

\section{RESULTS}

The objective results are summarised in Table I. On the whole Steindler's transplantation gave the best results, followed closely by Clark's pectoral transplantation, the other two types of transplantation being less satisfactory. However, the results require further analysis because 
TABLE I

OBjective Results

\begin{tabular}{|c|c|c|c|c|c|c|c|c|c|c|c|c|c|}
\hline \multirow{2}{*}{ Type of Operation } & \multicolumn{3}{|c|}{ Excellent } & \multicolumn{3}{|c|}{ Good } & \multicolumn{3}{|c|}{ Fair } & \multicolumn{3}{|c|}{ Failure } & \multirow{2}{*}{$\begin{array}{l}\text { Grand } \\
\text { totals }\end{array}$} \\
\hline & $\begin{array}{l}\text { Polio- } \\
\text { myelitis }\end{array}$ & $\begin{array}{l}\text { Brachial } \\
\text { plexus } \\
\text { injury }\end{array}$ & Total & $\begin{array}{l}\text { Polio- } \\
\text { myelitis }\end{array}$ & $\begin{array}{l}\text { Brachial } \\
\text { plexus } \\
\text { injury }\end{array}$ & Total & $\begin{array}{l}\text { Polio- } \\
\text { myelitis }\end{array}$ & $\begin{array}{l}\text { Brachial } \\
\text { plexus } \\
\text { injury }\end{array}$ & Total & $\begin{array}{l}\text { Polio- } \\
\text { myelitis }\end{array}$ & $\begin{array}{l}\text { Brachial } \\
\text { plexus } \\
\text { injury }\end{array}$ & Total & \\
\hline $\begin{array}{l}\text { Clark's } \\
\text { transplantation }\end{array}$ & 3 & 4 & 7 & 1 & - & 1 & - & 7 & 7 & 1 & 1 & 2 & 17 \\
\hline $\begin{array}{l}\text { Brooks-Seddon } \\
\text { transplantation }\end{array}$ & 1 & 1 & 2 & - & - & 一 & 1 & 2 & 3 & 1 & 2 & 3 & 8 \\
\hline $\begin{array}{l}\text { Steindler's } \\
\text { transplantation }\end{array}$ & 5 & 2 & 7 & 2 & - & 2 & 4 & - & 4 & - & - & - & 13 \\
\hline $\begin{array}{l}\text { Triceps } \\
\text { transplantation }\end{array}$ & - & - & - & 1 & - & 1 & 1 & 1 & 2 & - & - & - & 3 \\
\hline Total & 9 & 7 & 16 & 4 & - & 4 & 6 & 10 & 16 & 2 & 3 & 5 & 41 \\
\hline
\end{tabular}

there are certain advantages and disadvantages peculiar to each method. They are therefore considered under three headings: 1) the effect of operation on the range of passive movement of the elbow; 2) the effect of operation on active and passive supination of the forearm; and 3 ) associated movements occurring during active flexion.

Passive movement of the elbow (Table II)-Flexion has not been restricted by any operation performed in this series. Limitation of extension, however, has been a frequent sequel. The average limitation was about 30 degrees for all operations. It will be seen from Table II

TABLE II

Range of Passive Extension after Operation

\begin{tabular}{|c|c|c|c|c|c|}
\hline \multirow[b]{2}{*}{ Type of operation } & \multirow{2}{*}{$\begin{array}{c}\text { Full } \\
\text { movement }\end{array}$} & \multicolumn{3}{|c|}{ Restricted movement } & \multirow{2}{*}{ Total } \\
\hline & & $\begin{array}{l}\text { Less than } \\
30 \text { degrees }\end{array}$ & $\begin{array}{c}30-60 \\
\text { degrees }\end{array}$ & $\begin{array}{c}60-90 \\
\text { degrees }\end{array}$ & \\
\hline Clark's transplantation & 11 & 4 & 1 & 1 & 17 \\
\hline Brooks-Seddon transplantation & - & 7 & 1 & - & 8 \\
\hline Steindler's transplantation & - & 2 & 5 & 6 & 13 \\
\hline Triceps transplantation & - & 1 & 2 & - & 3 \\
\hline
\end{tabular}

that after Clark's operation eleven out of seventeen patients had full elbow movement; there had been pre-operative limitation of extension in four of the other six. Elbow extension is unlikely to be limited by more than 15 degrees after this operation. The Brooks-Seddon transplantation may restrict extension by about 25 degrees. Transplantation of the triceps may also produce a significant limitation of extension. It is hardly surprising that with the Steindler procedure, and particularly when (as is our practice) both flexor and extensor origins are transplanted, the restriction of extension is considerable. Loss of extension is the price paid for powerful flexion. The average loss of extension after Steindler's operation was 60 degrees. It seems probable that the power of triceps may influence the degree of limitation; in those cases in which triceps was acting at least against gravity the limitation of extension was about 45 degrees, whereas in the nine cases where it was less than the Medical Research Council grading of 3 the average limitation was 65 degrees.

VOL. 41 B, NO. 1, FEBRUARY 1959 
TABLE III

RaNGe of Supination after Operation

\begin{tabular}{|c|c|c|c|c|c|c|c|c|c|}
\hline \multirow{3}{*}{ Type of operation } & \multicolumn{8}{|c|}{ Range of movement in degrees } & \multirow{3}{*}{ Totals } \\
\hline & \multicolumn{2}{|c|}{ None } & \multicolumn{2}{|c|}{$0-45$} & \multicolumn{2}{|c|}{$0-75$} & \multicolumn{2}{|c|}{ Full } & \\
\hline & Passive & Active & Passive & Active & Passive & Active & Passive & Active & \\
\hline Clark's transplantation & - & 1 & 1 & 4 & 5 & 4 & 4 & 1 & 10 \\
\hline Brooks-Seddon transplantation & 1 & 3 & 3 & 1 & - & - & 1 & 1 & 5 \\
\hline Steindler's transplantation & 1 & 2 & 1 & 1 & 2 & 2 & 4 & 3 & 8 \\
\hline Triceps transplantation & 1 & 1 & - & 一 & 1 & 2 & 1 & - & 3 \\
\hline
\end{tabular}

Active and passive supination-It is important to know the effect of these operations on the range of active and passive supination of the forearm. It was possible to assess this effect in twenty-six cases in which there was full passive supination before operation (Table III). Clark's operation never restricted passive supination severely, and in all but one case restored a useful range of active supination. After the Brooks-Seddon transplantation passive supination was sometimes restricted; active supination was restored in only two out of five cases. The most significant conclusion to be drawn from this Table is that in our experience Steindler's transplantation has little effect on the range of passive supination.

In only five cases was there active supination through a complete range; once after Clark's operation, once after the Brooks-Seddon transplantation, and three times after Steindler's operation-almost certainly present before operation.

Associated movements (Table IV). Shoulder-Undesirable movements of the shoulder during active flexion of the elbow were a common sequel to pectoral transplantation and could seriously impair the result. The movements were shrugging, adduction, and medial rotation of the arm so that the hand hit the chest wall. Unless there was good muscular control of the shoulder and scapula, or unless an arthrodesis had been performed, this complication was frequent. When pectoral transplantation is carried out for lesions of the upper trunk of the brachial plexus, the paralysis is such that no active lateral rotation of the

TABLE IV

Associated Shoulder Movement after Pectoral Transplantation

\begin{tabular}{|c|c|c|c|c|}
\hline $\begin{array}{l}\text { Number } \\
\text { of cases }\end{array}$ & Shoulder muscles & $\begin{array}{l}\text { Marked medial rotation, } \\
\text { adduction, or shrugging } \\
\text { of the shoulder on flexion }\end{array}$ & Results & \\
\hline 7 & $\begin{array}{l}\text { Good control of the } \\
\text { shoulder and scapula }\end{array}$ & None & $\begin{array}{l}\text { Excellent } \\
\text { Failure }\end{array}$ & $\begin{array}{l}6 \\
1\end{array}$ \\
\hline 11 & $\begin{array}{l}\text { Variable scapular } \\
\text { control; no control } \\
\text { of the shoulder }\end{array}$ & $\begin{array}{l}1 \text { None } \\
10 \text { Present }\end{array}$ & $\begin{array}{l}\text { Excellent } \\
\text { Fair } \\
\text { Failures }\end{array}$ & $\begin{array}{l}2 \\
6 \\
3\end{array}$ \\
\hline 7 & $\begin{array}{l}\text { Arthrodesis of } \\
\text { the shoulder }\end{array}$ & None & $\begin{array}{l}\text { Excellent } \\
\text { Good } \\
\text { Fair }\end{array}$ & $\begin{array}{l}1 \\
2 \\
4\end{array}$ \\
\hline
\end{tabular}

arm is possible. Furthermore, in cases of poliomyelitis it is rare to find paralysis of the elbow flexors with normal control of the shoulder. In three of the seven cases in which arthrodesis of the shoulder was performed, it was carried out after the pectoral transplantation because 
of the undesirable effects just described. In the other four arthrodesis of the shoulder was performed before the transplantation.

Forearm muscles - In all of the thirteen patients on whom a modified Steindler operation had been performed contraction of the forearm muscles caused the hand to go into the clenched fist position during active flexion of the elbow. In only one case, however, was the strength or independence of wrist and finger movements affected, the patient flexing the elbow on attempted extension of the wrist. In no case has arthrodesis of the wrist had to be performed after Steindler's transplantation. One patient whose wrist extensors were weaker than the flexors wears a splint to prevent wrist flexion during active flexion of the elbow.

There is no doubt that after pectoral transplantation active flexion of the elbow is often reinforced by what may be termed " a Steindler effect." It is difficult to assess precisely how much this contributed to the final result. It can be said, however, that of nine patients without useful contributory forearm muscle action, three had excellent results after pectoral transplantation, compared with seven out of thirteen in whom the forearm muscles were strong. Triceps-In three cases-all of injuries of the brachial plexus-simultaneous contraction of triceps occurred on active flexion of the elbow, thus spoiling the result of the pectoral transplantation. In these three cases the triceps and the flexors of the elbow were paralysed when the patient was first seen. It is impossible to forecast this complication, for in six other cases in which the triceps was paralysed initially and recovered later no simultaneous flexorextensor action developed. This unhappy complication may be due to cross-regeneration, nerve fibres originally connected with the flexors of the elbow finding their way into distal pathways going to the extensors. In two cases a subsequent transplantation of the triceps into the flexor apparatus was successful.

Comparison of results in patients with poliomyelitis and brachial plexus injuries. Objective results-The twenty-one patients with poliomyelitis showed the following results:

$$
\begin{aligned}
& 9 \text { excellent } \\
& \left.\begin{array}{l}
4 \text { good } \\
6 \text { fair } \\
2 \text { failures }
\end{array}\right\}=62 \text { per cent } \\
& =58 \text { per cent }
\end{aligned}
$$

The results in the twenty patients with brachial plexus injuries were:

$$
\begin{aligned}
& \left.\begin{array}{l}
7 \text { excellent } \\
10 \text { fair } \\
3 \text { failures }
\end{array}\right\}=35 \text { per cent } \\
& =65 \text { per cent }
\end{aligned}
$$

The factors that might explain the better results in poliomyelitis are: 1) In the poliomyelitis series eleven Steindler transplantations were performed, whereas after brachial plexus injuries

\begin{tabular}{|c|c|c|}
\hline Type of operation & Excellent or good & Fair or failure \\
\hline Clark's transplantation & $8(47 \%)$ & $9(53 \%)$ \\
\hline Brooks-Seddon transplantation & $2(25 \%)$ & $6(75 \%)$ \\
\hline Total & $10(40 \%)$ & $15(60 \%)$ \\
\hline Steindler's transplantation & $9(69 \%)$ & $4(31 \%) \quad$ None is a failure \\
\hline
\end{tabular}

TABLE V

Comparison of Objective Results of Pectoral Transplantation and Steindler's Transplantation

there were only two. The results of Steindler's operation are better than those of pectoral transplantation (Table I and Table V). 2) Simultaneous contraction of the antagonist musclethe triceps-does not occur in poliomyelitis.

VOL. $41 \mathrm{~B}$, NO. 1, FEBRUARY 1959 
TABLE VI

Subjective Results: The Limb as a Whole

\begin{tabular}{|c|c|c|c|c|c|c|c|c|c|c|c|c|c|}
\hline \multirow[b]{2}{*}{ Type of Operation } & \multicolumn{3}{|c|}{ Excellent } & \multicolumn{3}{|c|}{ Good } & \multicolumn{3}{|c|}{ Poor } & \multicolumn{3}{|c|}{ Failure } & \multirow{2}{*}{$\begin{array}{l}\text { Grand } \\
\text { totals }\end{array}$} \\
\hline & $\begin{array}{l}\text { Polio- } \\
\text { myelitis }\end{array}$ & $\begin{array}{c}\text { Brachial } \\
\text { plexus } \\
\text { injury }\end{array}$ & Total & $\begin{array}{l}\text { Polio-- } \\
\text { myelitis }\end{array}$ & $\begin{array}{c}\text { Brachial } \\
\text { plexus } \\
\text { injury }\end{array}$ & Total & $\begin{array}{l}\text { Polio- } \\
\text { myelitis }\end{array}$ & $\begin{array}{c}\text { Brachial } \\
\text { plexus } \\
\text { injury }\end{array}$ & Total & $\begin{array}{l}\text { Polio- } \\
\text { myelitis }\end{array}$ & $\begin{array}{c}\text { Brachial } \\
\text { plexus } \\
\text { injury }\end{array}$ & Total & \\
\hline $\begin{array}{l}\text { Clark's } \\
\text { transplantation }\end{array}$ & 2 & - & 2 & 2 & 6 & 8 & 1 & 5 & 6 & - & 1 & 1 & 17 \\
\hline $\begin{array}{l}\text { Brooks-Seddon } \\
\text { transplantation }\end{array}$ & - & - & - & 3 & 1 & 4 & - & 1 & 1 & - & 1 & 1 & 6 \\
\hline $\begin{array}{l}\text { Steindler's } \\
\text { transplantation }\end{array}$ & 3 & 1 & 4 & 6 & 1 & 7 & 2 & - & 2 & - & - & - & 13 \\
\hline $\begin{array}{l}\text { Triceps } \\
\text { transplantation }\end{array}$ & - & - & - & 1 & - & 1 & 1 & 1 & 2 & - & - & - & 3 \\
\hline Total & 5 & 1 & 6 & 12 & 8 & 20 & 4 & 7 & 11 & - & 2 & 2 & 39 \\
\hline
\end{tabular}

Subjective results (Table VI) - It has been impossible for the patients, almost all of whom had undergone other operations on the affected limb, to assess precisely how much benefit they derived from the operation on the elbow. However, they were asked a number of detailed questions about what they could do before and after the operation.

The twenty-one patients with poliomyelitis showed the following results:

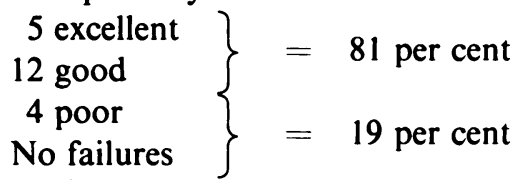

The results in the eighteen* patients with brachial plexus injuries whose functional results could be assessed were:

$$
\begin{aligned}
& \left.\begin{array}{l}
1 \text { excellent } \\
8 \text { good } \\
7 \text { poor } \\
2 \text { failures }
\end{array}\right\}=50 \text { per cent } \\
& =50 \text { per cent }
\end{aligned}
$$

Although there were fifteen patients who stated that they could use the hand at the level of the face, only nine in fact habitually did so. When patients are accustomed to use the normal

TABLE VII

Functional Results: Elbow Alone

\begin{tabular}{|lcccc|}
\hline Results & \multicolumn{2}{c}{$\begin{array}{c}\text { Brachial plexus } \\
\text { injury }\end{array}$} & Poliomyelitis & Total \\
\cline { 1 - 1 } Excellent & & 12 & 18 & 30 \\
Good. & 1 & & 1 & 2 \\
Poor. & 5 & 1 & 6 \\
Failure . & - & 1 & 1 \\
\hline & 18 & 21 & 39 \\
\hline
\end{tabular}

limb their only need is to be able to use the affected limb as a help. Consequently, even if they are unable to flex the affected elbow fully function is very good. Twenty patients said that the appearance of the arm had been much improved by the elbow operation, because it

* The other two had amputations through the forearm. 
no longer hung limply by the side. No patient complained of the change in appearance due to a 50-90 degrees' flexion deformity of the elbow.

The functional results with reference to the elbow operation alone are summarised in Table VII. It shows clearly how a patient is often better pleased with the operation than is his surgeon. The one failure was after a triceps transplantation when active flexion was not regained and the loss of active extension was regretted.

\section{DISCUSSION}

Muscle transplantation is more effective when it is not required to move the elbow through the first 30 or $\mathbf{4 0}$ degrees of flexion. The results (assessed objectively) were better when passive extension of the elbow was limited.

In eleven patients with full extension the results were:

$$
\begin{array}{ll}
4 \text { satisfactory } & =36 \text { per cent } \\
7 \text { inferior results or failures } & =64 \text { per cent }
\end{array}
$$

In thirty patients with limited extension the results were:

$$
\begin{array}{ll}
16 \text { satisfactory } & =53 \text { per cent } \\
14 \text { inferior results or failures } & =47 \text { per cent }
\end{array}
$$

When the failures are analysed it becomes apparent that unless a muscle is really strong it is not worth transplanting. For example, in four cases of pectoral transplantation the muscle was weak; it just failed, or was just able to contract against gravity. In two other patients the pre-operative power of the muscle was over-estimated. In a severely paralysed limb it is often tempting to overrate the muscle that is to be transplanted.

\section{COMPARISON OF OPERATIVE TECHNIQUES}

Clark's method-This operation rarely limits passive extension of the elbow, which may be a disadvantage. Some active supination is usually restored. It has been impossible to determine whether Clark's transplantation can reinforce a weak biceps, or whether it in fact eliminates such action as is present. It is probable that it does the latter, as can be demonstrated in transplantations carried out elsewhere in the body. If this is so, then transplantation should not be carried out until hope of recovery in the biceps has been abandoned.

Brooks-Seddon method-This technique was devised for those patients in whom either the lower part of pectoralis major was paralysed, the clavicular head being strong, or when the whole muscle was weak. In other words, it was employed for patients who were more severely paralysed than those in whom a Clark transplantation had been carried out.

In both pectoral transplantations there is an indication for arthrodesis of the shoulder in those patients who lack adequate muscular stabilisation of the shoulder. The effectiveness of pectoral transplantation may be enhanced by a "Steindler effect," and when this is so it might well be argued that a proximal transplantation of the flexor and extensor origins would have been preferable. Furthermore, the effectiveness of a Steindler transplant is not so directly concerned with shoulder stability as is the pectoral transplant.

Steindler's method-Transplantation of the flexor and extensor origins can be used to reinforce a weak biceps without either hindering its action or prejudicing further recovery-an important feature in traction lesions of the brachial plexus. Similarly, Steindler's transplant can be used to reinforce a feebly acting pectoral transplant (Le Coeur 1953). The disadvantages of the Steindler transplant are, of course, that any relaxation of the grip allows the elbow to extend. Elbow extension is always limited, the impairment amounting on an average to 60 degrees, though this is often advantageous. Like Carroll and Gartland (1953), and unlike Mayer and Green (1954), we have not aimed at correcting the post-operative contracture. In our experience a pronation deformity is unlikely to result from this operation.

Triceps transplantation-Only one of three operations was a complete success. Loss of active extension is such a disadvantage that it greatly restricts the indications for this operation.

VOL. 41 B, NO. 1, FEBRUARY 1959 
One patient complained bitterly of the fact that she was unable to steady a loaf with her hand while cutting a slice of bread. Its use should be reserved for those cases in which restoration of flexion is imperative, and in which no other transplantation is possible; or in rare instances when simultaneous contraction of triceps interferes with the action of a pectoral transplant or biceps.

Which operation should be done when there are several possibilities? The most important choice lies between pectoral transplantation and Steindler's operation. When there is a free choice the latter is preferable, because pectoral transplantation usually calls for arthrodesis of the shoulder if there is appreciable paralysis of the shoulder muscles; and if there is some action in the biceps it will be reinforced by Steindler's transplantation, whereas it is by no means certain that this is the case with Clark's transplantation. The Brooks-Seddon technique should never be employed unless the biceps is completely and permanently paralysed.

\section{SUMMARY}

1. Twenty-one cases of poliomyelitis and twenty cases of brachial plexus injury in which muscle transplantations had been performed to restore elbow flexion have been reviewed. The average follow-up period was four and a half years.

2. The results were graded objectively and subjectively. They were better when passive extension of the elbow was limited; such limitation always occurs after Steindler's operation, but infrequently after pectoral transplantation.

3. The results of pectoral transplantation are good when there is no significant shoulder paralysis; if there is shoulder weakness arthrodesis of the joint may be required to control medial rotation and adduction of the shoulder on flexion of the elbow. In brachial plexus lesions the results of pectoral transplantation may be marred by simultaneous contraction of the triceps. This can be overcome by transplanting triceps into the flexor apparatus. Triceps transplantation is rarely indicated because loss of active extension of the elbow is a grave disability.

4. Subjective results tended to be worse than objective results in brachial plexus lesions because impairment of sensibility in the hand often limited the usefulness of the limb. In striking contrast the subjective results were in general far better than the objective in patients who had had poliomyelitis. In them the smallest gain can be of functional value.

Dr Segal worked in the Insititute of Orthopaedics in 1956 while holding an Anglo-French Exchange Scholarship in Medical Science.

\section{REFERENCES}

Brooks, D. M., and Seddon, H. J. (1959): Pectoral Transplantation for Paralysis of the Flexors of the Elbowa new technique. Journal of Bone and Joint Surgery, 41-B, 36.

Carroll, R. E., and Gartland, J. J. (1953): Flexorplasty of the Elbow. An Evaluation of a Method. Journal of Bone and Joint Surgery, 35-A, 706.

Clark, J. M. P. (1946): Reconstruction of Biceps Brachii by Pectoral Muscle Transplantation. British Journal of Surgery, 34, 180.

Le Coeur, P. (1953): Procédés de Restauration de la Flexion du Coude Paralytique. Revue de Chirurgie Orthopédique, 39, 655.

MAYer, L., and Green, W. (1954): Experiences with the Steindler Flexorplasty at the Elbow. Journal of Bone and Joint Surgery, 36-A, 775. 